Robert Kłosowicz (D)

Institute of Political Science and International Relations

Jagiellonian University

\title{
TADEUSZ LEWICKI'S ACADEMIC ACHIEVEMENTS IN THE FIELD OF AFRICAN STUDIES
}

\section{sis}

I

N JANUARY 2016, we celebrated the $110^{\text {th }}$ anniversary of the birth of an accomplished scholar whose academic achievements could be classified as part of the African studies field. Professor Tadeusz Lewicki, even though he is known mostly as one of the most renowned Polish Orientalists, a specialist in Arabic studies and medieval historian, could from today's perspective easily be referred to as one of the pioneers of African studies in Poland. When Professor Lewicki began to function as a fully mature researcher, African studies in Poland were only in the early stages of formation, which is why his achievements within the scope of African issues are usually classified as part of Oriental studies. ${ }^{1}$ The researcher frequently referred to himself as a representative of African studies,

1 In her memoirs, Dr Alicja Małecka, one of the professor's closest colleagues, refers to Lewicki as an "Arabist and Africanist", cf. A. MAŁEC- 
which to his understanding was part of Oriental studies. ${ }^{2}$ The aim of this chapter is to provide information about an accomplished researcher, an Arabist and Africanist, with a well-established international reputation and who was associated with the Jagiellonian University, with special note of his achievements in the field of African studies.

Tadeusz Lewicki was born on $26^{\text {th }}$ January 1906 in Lviv (Polish: Lwów) in a family belonging to local intellectual circles and with gentry origins. His father was a renowned lawyer. In 1919, at the age of 13, Lewicki took part in the struggle for retaining the Polishness of Lviv against Ukrainian nationalists, joining the ranks of a group of Polish volunteers known as the Lviv Eaglets (Orlęta Lwowskie). In 1925, he graduated from Casimir the Great's $8^{\text {th }}$ State Real Gymnasium in Lviv, while in 1927 he began studying law at the Humanities Faculty at the Jan Casimir University, in this way following family tradition. However, as he dreamt of pursuing a career in diplomacy in one of the Muslim countries, he left for Paris in 1928, where he studied political science and Eastern languages. ${ }^{3}$ At that time, he also travelled to Algeria for a few months, where he spent his time in an Arabic-speaking environment. He learnt the language and culture of the country in one of the oases near the town of Biskra, situated in the foothills of the Au-

KA, Profesor Tadeusz. Wspomnienie o Profesorze Tadeuszu Lewickim (19061992), "Cracovia Leopolis" 1998, no. 15, p. 8.

2 T. LEWICKI, Najważniejsze problemy historiografii Afryki Subsaharyjskiej na Międzynarodowym Kongresie Historii Afryki w Dar es Salaam (26 IX - 3 X 1965), "Etnografia Polska" 1968, vol. 12, p. 225; interview with Dr U. Lewicka-Rajewska, Professor T. Lewicki’s daughter, 20.06.2016.

3 A. MAŁECKA, op. cit., p. 10. 
res Mountains. ${ }^{4}$ During that period, he hiked through the Sahara to Tripolitania, wearing Bedouin clothing and accompanying camel shepherds. As he later recalls, this was when he came to the important decision to change what he was studying. ${ }^{5}$

Upon his return to Lviv, Lewicki quit his legal studies, and dedicated himself to Oriental studies under the supervision of the accomplished Arabist, Professor Zygmunt Smogorzewski (1884-1931), a former diplomat of the Russian Empire and earlier the Russian vice-consul in Algeria. ${ }^{6}$ From this last country, Smogorzewski brought a collection of previously unstudied Ibadi manuscripts. ${ }^{7}$ He also acquired a lot of information from Kalasanty Motylinski, a French expert in Arabic studies with Polish origins. ${ }^{8}$ As of 1930, Smogorzewski, who was having increasingly more issues with his health, found a successor in Lewicki and infected his student

4 In Antiquity, Biskra was a Roman city called Vescera, located at the crossroads of the caravan routes from the Sahara to the Mediterranean coast.

5 J. BubKa, B. Ostafin, Tadeusz Lewicki (1906-1992), [in:] Studia Orientalia Thaddaeo Lewicki Oblata. Materiaty sesji naukowej poświęconej pamięci profesora Tadeusza Lewickiego, Kraków, 17-18 listopada 1993, ed. by E. GórsKA, B. OstAFIN, Uniwersytet Jagielloński, Instytut Filologii Orientalnej, Kraków 1994, p. 167.

6 Zygmunt Smogorzewski, Internetowy Polski Słownik Biograficzny, [on-line:] http://www.ipsb.nina.gov.pl/index.php/a/zygmunt-smogrze wski - 16.05.2016.

7 Most of the manuscripts he collected later became part of the Lviv University collections.

8 Gustaw Adolf Kalasanty Motyliński (1854-1907) - the son of a Polish emigrant, born in French Algeria, a researcher of Africa, expert in Arabic culture and language, an Orientalist and traveller. As a translator in the French Foreign Legion, he went on numerous expeditions into the Saharan interior. Motyliński founded the Higher School of Arabic Studies in Constantine. He specialised in research into the Ibadi, cf. Wielka Encyklopedia PWN, PWN, Warszawa 2003, vol. 18, p. 147. 
with an interest in the Ibadi from the Maghreb region. ${ }^{9}$ In 1931, Lewicki, who at the time was Smogorzewski's assistant, earned his $\mathrm{PhD}$ degree on the basis of a thesis about the history of North Africa during the early Middle Ages, written under the supervision of his master. ${ }^{10}$

In November 1931, Prof. Smogorzewski died and due the lack of a successor - the Department of Oriental Studies at the Jan Casimir University in Lviv was closed down. Lewicki was then employed by the Department of Ancient History, directed by Prof. Konstanty Chyliński. In 1932-1934, Lewicki went on a scholarship to France, where he was able to study at Parisian universities - the Sorbonne and the Collège de France, coming into contact with such famous scholars as the renowned expert on Muslim mysticism Louis Massignon or the specialist in Arabic studies William Marçais. He then travelled to the main Ibadi centres in the Algerian Sahara - the oases M'zab, Beni Isguen and Ouargla, where he studied Ibadi manuscripts on site. ${ }^{11}$ This research resulted in a series of articles in the most renowned academic journal specializing in Islamic issues "Revue des Études Islamiques". ${ }^{12}$

9 The Ibadi - a moderate Khariji sect, which appeared in Al-Iraq towards the end of the $7^{\text {th }}$ century and spread primarily among the Maghreb Berbers, cf. J. Sourdel, D. Sourdel, Cywilizacja islamu, trans. by M. SkurAtowicz, W. Dembski, PIW, Warszawa 1980, p. 477.

10 Archive of the Jagiellonian University [herein referred to as: AJU], ref. no. III 246, T. Lewicki's personnel file, Statement about T. Lewicki's PhD written by Prof. W. Podlacha (21.03.1949) and Dr A. Klawka (23.02.1949); A. MAŁECKA, op. cit., pp. 10-11.

${ }_{11}$ Interview with Dr U. Lewicka-Rajewska, Professor T. Lewicki's daughter, 20.06.2016.

12 A. ZABORski, Min Bìād Aş-Şaqāliba Ilā Bilād As-Sūdān - od Stowiańszczyzny po Sudan, [in:] Studia Orientalia Thaddaeo Lewicki Oblata..., pp. 7-8. 
In the second half of the 1930s, Lewicki, employed as older assistant at the Department of Ancient History at the Jan Casimir University, became involved in research into the Arabic sources describing the history of the Slavic regions. These became an important field of his research also over the next years, and resulted in the book entitled Polska i kraje sqsiednie w świetle "Księgi Rogera", geografa arabskiego z XII w. al-Idrisiego (uwagi ogólne, tekst arabski, tłumaczenie) [Poland and its neighbouring countries in light of "Roger's Books", by the $12^{\text {th }}$-century Arabic geographer, al-Idrisi (general commentary, Arabic text, translation)] published in Kraków in 1945, which later became the basis for initiating the procedures necessary to obtain his habilitation degree, completed by his habiliation colloquium in 1949. ${ }^{13}$ His studies into the Arabic manuscripts on the history of the Slavic regions led to him first becoming acquainted and then fast friends with the renowned specialist in Arabic studies from Kraków, Professor Tadeusz Kowalski, the director of the Department of Oriental Philology at the Jagiellonian University, which will have a significant influence on Lewicki's later post-war fortunes and his academic career. ${ }^{14}$

During World War II, Lewicki fought in the partisan forces in the Zamojskie region as a soldier of the Home Army (Armia Krajowa). He was also the editor of the partisan newspaper "Echa Leśne" [Forest echoes]. He

13 Archive of the Jagiellonian University [herein referred to as: AJU], ref. no. III 246, T. Lewicki's personnel file, Statement about T. Lewicki's PhD written by Prof. W. Podlach (21.03.1949) and Dr A. Klawka (23.02.1949).

${ }_{14}$ Interview with Dr U. Lewicka-Rajewska, Professor T. Lewicki's daughter, 20.06.2016. 
later participated in the Warsaw Uprising in the rank of sub-lieutenant as commander of the RPG platoon in the $1^{\text {st }}$ sub-district in the "Chrobry II" group. ${ }^{15}$ After the uprising ended, he was a prisoner of war in the Murnau Oflag in Bavaria. After the camp was liberated by American forces, he remained in Germany for some time, serving in the picket in the American occupation zone. In 1946, he came to Italy and became a soldier of the Second Corpus. In Fermo, he taught Polish history and literature in the Gymnasium and Mechanical Lyceum of the Second Corpus of the Polish Military Forces in the West. He was then evacuated to Great Britain, where he stayed for a short time and then returned to his homeland in $1947 .{ }^{16}$

Upon his return, Lewicki settled in Kraków, where he started working in the Polish Academy of Arts and Sciences. In August 1949, he was employed by the Jagiellonian University, where he worked until he retired. ${ }^{17}$ Initially, he taught the Arabic language, but after he obtained his habilitation degree in December 1949, he was appointed to the position of deputy professor in the Department of Oriental Philology at the Faculty of the Humanities. ${ }^{18}$ In 1951, he was appointed the head of the Department of Oriental Philology, which in 1972 was transformed into

15 Tadeusz Lewicki, [in:] Powstańcze biogramy, [on-line:] http://www. 1944.pl/historia/powstancze-biogramy/Tadeusz_Lewicki_1-14.05.2016.

${ }_{16}$ K. KościelniaK, The contribution of Prof. Tadeusz Lewicki (19061992) to Islamic and West African Studies, "Analecta Cracoviensia" 2012, vol. 44, p. 243.

${ }_{17}$ AUJ, reg. no. SIII 246, T. Lewicki's personnel file, Work contract concluded with the Rector of the Jagiellonian University, 24.10.1949.

18 Ibidem, Deanery of the Faculty of the Humanities, Jagiellonian University in Kraków, Confirmation of Dr Tadeusz Lewicki's habilitation in the field of Arabic philology, 29.12.1949. 
the Institute of Oriental Philology. ${ }^{19}$ For many years, Professor Lewicki was the chair of the Committee of Oriental Sciences of the Polish Academy of Sciences. He is merited with having expanded Oriental studies at the Jagiellonian University and with the formation of African studies specialisations within its framework. ${ }^{20}$

At the beginning of the 196os, as a result of the decolonisation of Africa and the formation of independent states, interest in the continent increased, which led to the development of African studies and, in some countries, the formation of appropriate departments; such a situation also occurred in Poland. ${ }^{21}$ Thanks to his interest in the Ibadi and the history of medieval Africa, Professor Lewicki, as an accomplished expert on Arabic sources, was one of the few researchers in Poland to be well prepared for conducting studies into the history of Africa. It is no coincidence that Professor Lewicki published the highest amount of publications and participated in the largest amount of academic conferences on African studies issues during this period (1960-1970). His extensive proficiency resulting to the education he had obtained in the fields of philology and Arabic studies, including his fluency in Arabic, his broad historical and geographical knowledge of the region, expanded

19 Ibidem, Confirmation of the reception of the appointment of Dr Tadeusz Lewicki as director of the Department of Oriental Philology, the Ministry of Higher Education, Personnel Department, Department of Autonomous Academic Personnel in Warsaw, 20.08.1953.

20 K. MaciuszaK, $Z$ historii orientalistyki na Uniwersytecie Jagiellońskim, “Alma Mater" 2009-2010, no. 120-121, p. 139.

${ }_{21}$ The first African studies department in Poland was formed at the University of Warsaw in 1969 as the Department of Semitic and African Studies, cf. [on-line] http://www.afrykanistyka.uw.edu.pl/o-katedrze - 5.06.2016. 
as a result of the research he did in the field in the 1930s, aided him in conducting comprehensive studies of Arabic sources on the history of Africa, which was reflected in his publications, such as Arabic External Sources for the History of Africa to the South of Sahara, ${ }^{22}$ Źrodta arabskie do dziejów Afryki na potudnie od Sahary [Arabic sources on the history of Africa south of the Sahara], ${ }^{23}$ Dzieje Afryki od czasów najdawniejszych do XIV w. Wybrane zagadnienia [The History of Africa from the most ancient times to the $16^{\text {th }}$ century. Selected issues]. ${ }^{24}$ His interests, previously limited to North Africa, were expanded to include the study of areas south of the Sahara. ${ }^{25}$ Especially his achievements as a researcher of the medieval history of Western Sudan place him among the most renowned experts on this topic in the world.

Lewicki was also fascinated by the political and trade contacts between the Muslim world and the inhabitants of Sub-Saharan Africa living both on the east and the west coasts of the continent, as a consequence of which the following texts were published: $Z$ dziejów handlu transsaharyjskiego. Kupcy i misjonarze ibādyccy w zachodnim i środkowym Sudanie $w$ VIII-XII $w$. [From the history of trans-Saharan trade: Ibadi merchants and missionaries in the western

22 T. LEWICKI, Arabic External Sources for the History of Africa to the South of Sahara, Zakład Narodowy im. Ossolinskich, Wydawnictwo Polskiej Akademii Nauk, Wrocław - Warszawa - Kraków 1969.

${ }_{23}$ IDEM, Źródła arabskie do dziejów Afryki na południe od Sahary, "Etnografia Polska" 1965, vol. 9, pp. 221-293.

${ }_{24}$ IDEM, Dzieje Afryki od czasów najdawniejszych do XIV w. Wybrane zagadnienia, Uniwersytet Warszawski. Studium Afrykanistyczne, Warszawa 1969.

${ }_{25}$ IDEM, Z przeszłości Zachodniej Afryki, "Materiały Zachodniopomorskie" 1965, vol. 11, pp. 679-717; IDEM, Pożywienie ludności Zachodniej Afryki w średniowieczu według źródeł arabskich, "Etnografia Polska" 1963, vol. 7, pp. 31-191. 
and central Sudan in the $8^{\text {th }}-12^{\text {th }}$ centuries]; ${ }^{26}$ Najstarsza wzmianka o stosunkach Arabii muzutmańskiej ze wschodnim wybrzeziem Afryki [The oldest mention of Muslim Arabia relations on the eastern coast of Africa]. ${ }^{27}$

In 1965, Professor Lewicki was invited to the International Congress of African History, organized by the University College in Dar es Salaam, in cooperation with the government of the United Republic of Tanzania and with the support of UNESCO. Over one hundred and forty delegates from around the world participated in the Congress, which took place from $26^{\text {th }}$ September to $2^{\text {nd }}$ October 1965. A debate was organized on issues related to the history of Sub-Saharan Africa and the teaching of history in African schools. The president of Tanzania, Julius Nyerere, took part in the opening ceremony of the congress. It is worth mentioning that Lewicki was the only Polish representative at the Congress and - as he himself put it - he represented Polish African studies there, presenting the paper Arabic Sources for the History of Africa to the South of Sahara. ${ }^{28}$

One of the most important positions among the Professor's academic legacy is his research into the Ibadites. In 776, the Ibadites formed an independent and stable community in the centre of Tahert (currently Tiaret in Algeria), referred to as "small Al-Iraq". For one and a half centuries, this town was a centre distinguished by rich intellectual

${ }^{26}$ IDEM, $Z$ dziejów handlu transsaharyjskiego: kupcy $i$ misjonarze ibādyccy w zachodnim i środkowym Sudanie w VIII-XII w., "Przegląd Orientalistyczny” 1961, no. 1, pp. 3-18; IDEM, $Z$ przeszłości Nubii [On Nubia’s past], "Przegląd Orientalistyczny" 1965, no. 3, pp. 215-228.

${ }_{27}$ IDEM, Najstarsza wzmianka o stosunkach Arabii muzułmańskiej ze wschodnim wybrzeżem Afryki, copied from: "Sprawozdanie z posiedzeń Komisji Oddziału PAN w Krakowie” 1962 (January-June).

${ }_{28}$ IDEM, Najważniejsze problemy historiografii..., pp. 225-264. 
and economic output, from which the Ibadites controlled regional trade over large distances. In a short time, they brought the Berbers under their control in large areas of the Maghreb and Libya. ${ }^{29}$ Lewicki's research showed that the north-western trade routes leading from the towns located by the Mediterranean Sea through the Sahara to Sudan (bilād as-Südān) ${ }^{30}$ functioned mainly due to the Ibadites from North Africa. Thanks to the Ibadi settlements, the lands of Sudan maintained contact with the world, while the towns located on the caravan routes became richer thanks to the trade, within the frameworks of which salt from the Sahara mines was exchanged for millet, gold, ivory, horses and slaves from Sub-Saharan Africa. For example, the Ibadites from the Tripolitania region maintained trade contacts with the inhabitants of areas surrounding Lake Chad. The merchants were followed by missionaries, who spread Islam to the area. ${ }^{31}$ Lewicki claimed that one of the earliest routes between Tāhert, Ouargla and Sudan was established at the turn of the $8^{\text {th }}$ and $9^{\text {th }}$ centuries.

29 J. SOURDEL, D. SOURDEL, op. cit., pp. 554, 570.

3o Sudan, in Arabic bilād as-Sūdān - "The Land of the Black People". This term was used to refer to the lands of subtropical Africa, where Islam arrived in the Middle Ages. It refers to a geographical and historical land that covered the area between the Sahel and the equatorial (tropical) rain forests, as well as between the Abyssinian plateau and the Atlantic Ocean. Historical Sudan is divided into three parts: West Sudan encompassing the basin of Senegal and Central Niger, extending from the Atlantic Ocean to Lake Chad, in contemporary times encompassing such countries as Senegal, Gambia, Guinea-Bissau, Mali, Niger; Central Sudan - from the borders of the present-day Republic of Sudan and covering most of today's Republic of Chad; East Sudan - encompassing the basin of the Upper Nile and presently constituting a large part of the current territory of the Republic of Sudan, cf. ibidem, p. 563.

${ }^{31}$ K. KościelniaK, op. cit., pp. 247-248. 
More or less at this same time, a second trade route between Tādmekka, Ouargla, Tozeur and Qayrawān was established. Somewhat later, yet another, third trade route was opened, leading through the settlements of Ouargla, M'zab and Oued Righ. ${ }^{32}$ Lewicki's research regarding the Islamisation of substantial areas of Western Sudan and Central Sudan by the Ibadites between the $8^{\text {th }}$ and the $14^{\text {th }}$ centuries, based on an acute analysis of Ibadi sources, became an inspiration for many later researchers of these issues and add extensive amounts of information about the shaping of the relations between the Arabic-Berber population of North Africa and the Negroid population of Sub-Saharan Africa. ${ }^{33}$ As a result, the Professor's interest in the Ibadites also included the history of Berber tribes and their Islamization. ${ }^{34}$ One such example can be the research

32 T. LEWICKI, L'État nord-africain de Tāhert et ses relations avec le Soudan occidental à la fin du VIIIe et au IXe siècle, "Cahiers d'Études Africaines" 1962, vol. 2, pp. 513-535. For more see: IDEM, Traits d'histoire du commerce transsaharien. Marchands et missionaires ibâdites au Soudan occidental et central au cours des VIIle-Xe siècles, "Etnografia Polska" 1964, vol. 8, pp. 291-311; IDEM, Les origines et l'islamisation de la ville de Tâdmakka d'après les sources arabes, "Revue Française d'Histoire d'Outre-Mer" 1979, vol. 46, pp. 163-168; K. KościelniAK, op. cit., p. 248.

33 T. LEWICKI, The Role of the Sahara and Saharians in the Relationships between North and South, [in:] General History of Africa, vol. 3: Africa from the $7^{\text {th }}$ to the $11^{\text {th }}$ Century, ed. by I. HRBEK, London 1992, p. 151; IDEM, The Ibadites in Arabia and Africa, "Journal of World History" 1971, vol. 13, p. 117; IDEM, Les Sources Ibādites de L'Histoire Médiévale De L’Afrique Du Nord, "Africana Bulletin" 1988, no. 35, pp. 31-42; K. KościelniAK, op. cit., p. 248.

34 T. LEWICKI, Un État soudanais médiéval inconnu le royaume de Zāfūn(u), “Cahiers D’Études Africaines" 1971, no. 44, pp. 501-525; IDEM, Les Noms Propres Berbères Employés Chez Les Nafūsa Médiévaux (VIIIXVI Siècle), "Folia Orientalia" 1972-1973, vol. 16, pp. 5-35; IDEM, L'origine nord-africaine des Bafour, [in:] Actes du Deuxième Congrès International D’Étude des Cultures de la Méditerranée Occidentale, Alger 1978, pp. 145- 
he did into the African kingdom of Zawila, which was part of present-day eastern Fezzan, over which the Ibadi elites managed to gain control. ${ }^{35}$

In 1974, an important publication by Prof. Lewicki was published in English - West African food in the Middle Ages. According to Arabic Sources, ${ }^{36}$ which brought him fame internationally in African studies circles. To this day, Lewicki's research has a lot of significance for historians focusing on the economy of the West African peoples in the Middle Ages, as - based on the available written sources - he reconstructed the diet at the time of the inhabitants of this area before the arrival of plants from both Americas, such as corn, manioc, peanuts, red peppers or tomatoes. His book was published by Cambridge University Press and received 26 reviews by renowned scholars. Lewicki's research showed that the population in the described area ate mostly wild rice (currently almost forgotten), beans, and any vitamin deficiencies were supplemented by drinking baobab leaf juice. ${ }^{37}$ As a result, by delving into the texts of medieval

153; IDEM, Les Origines De L’islam Dans Les Tribus Berbères Du Sahara Occidental: Mūsā Ibn Nuşayr Et 'Ubadyt Allāh Ibn Al.-Habhāb, [in:] Ex fasciulo XXXII Memoriae J. Schacht Dedico "Studia Islamica", Paris 1970, pp. 203214; IDEM, Quelques extraits inédits relatifs aux voyages des commerçants et des missionaires ibādites nord-africains au pays du Soudan occidental au Moyen Âge, "Folia Orientalia" 196o, vol. 2, pp. 1-27.

35 Fezzan (Fazzān) is a historic land located in the south-west region of present-day Libya, inhabited by the Berber Garamants, the descendants of the present-day Tuaregs, from the $5^{\text {th }}$ century BC until the $7^{\text {th }}$ century AD, cf. IDEM, $Z$ przeszłości Afryki zachodniej, "Materiały Zachodniopomorskie" 1965, vol. 11, pp. 679-717.

36 IDEM, West African food in the Middle Ages. According to Arabic Sources, Cambridge University Press, London 1974.

37 IDEM, Pożywienie ludności Zachodniej Afryki..., pp. 65-70, 108-110. 
Arabic historians and geographers, he managed to reconstruct a lot of information about the social and economic situation of the inhabitants of West Africa during this period, and - thus - contradicting the widespread opinion in the academic world at the time that no strong, organised state could have developed in Sub-Saharan Africa due to the lack of suitable food. ${ }^{8}$ The conclusions gathered from the Arabic texts are to this day used in the research conducted by contemporary historians and ethnographers.

Professor Lewicki, inspired by the suggestions made by William Marçais, returned to his research into the remnants of the Romance language in the onomastics of North Africa. After analysing a series of Arabic sources, he noticed that in various towns in the Maghreb in which the local population had been Romanized during the period of the Roman Empire, remnants of the Romance language were preserved for a few centuries after the conquest of this region by the Arabs. Evidence of this can be observed, for example, in the writings of the Arabic geographer al-Idrisi, who in the mid-12 $2^{\text {th }}$ century stayed for a number of years at the court of the Norman king of Sicily, Roger II. Al-Idrisi noted that the inhabitants of Gafsa, a town located in southern Tunisia, used a Latin-African language, which would attest that the Romance language remained in use in some parts of the Maghreb in the $12^{\text {th }}$ century. No texts in this language have been preserved; however, Prof. Lewicki analysed the Romanesque onomastic material contained in the Arabic sources, which was not easy as the

${ }^{8}$ According to the widespread opinion in the academic world at the time, a strong state cannot develop on the foundation of a gatherer or hunter economy, as only an economy based on the cultivation of plants can provide a basis for the construction of a functional state. 
Arabic alphabet is not suited to rendering the sounds of the Latin-African language. ${ }^{39}$ Tadeusz Lewicki's considerations were included in the dissertation entitled Une langue romane oubliée de l'Afrique du Nord published in the journal "Rocznik Orientalistyczny", ${ }^{40}$ preceded by a statement announcing another dissertation, later issued in the bulletin of the Polish Linguistic Association in 1950 with the title Szczątki języka romańskiego w pólnocno-zachodniej Afryce $w$ epoce arabskiej [Remnants of the Romance language in north-west Africa in the Arabic era]. Prof. Lewicki's dissertation met with a lot of interest among linguists, as attested by the reviews published in the most prestigious scholarly periodicals.

An important position among the scholar's publications is one entitled Arabic External Sources for the History of Africa to the South of Sahara (Wrocław - Warszawa - Kraków 1969). This text contains an excellent analysis of Arabic sources on the history of medieval Africa south of the Sahara. The book was written on the basis of lectures Lewicki prepared to present at a university in Ghana, where he was invited as a visiting professor. However, he withdrew from going on the trip following the coup d'état that occurred in February 1966, as a result of which Kwame Nkrumah was overthrown..$^{41}$

Tadeusz Lewicki also contributed to research into the historical geography of Africa through his studies into old

39 W. MAŃczaK, Prace romanistyczne profesora Tadeusza Lewickiego, [in:] Studia Orientalia Thaddaeo Lewicki Oblata..., pp. 15-17.

$4^{\circ}$ T. LEWICKI, Une langue romane oubliée de l'Afrique du Nord. Observations d'un arabisant, "Rocznik Orientalistyczny" 1953, vol. 17, pp. 415480 .

${ }^{41}$ A. ZABORSKI, op. cit., p. 11; T. LEWICKI, Arabic External Sources... 
maps and the identification on their basis of historical African states. The aforementioned maps were issued systematically in Europe as of the $13^{\text {th }}$ century; however, the oldest preserved one originates from 1339. Those drawing the maps mainly consisted of Catalans from Majorca and Italians. They based their drawings on information provided by both European and Arabic merchants who at the time ventured further inland into the African continent. ${ }^{42}$

During his long academic career, Lewicki conducted research in African countries: Senegal, Algeria, Mauretania, Cameroun and Tanzania. His last trip to Africa (Algeria - M'zab) took place in 1984, when the professor was 78 years old. ${ }^{43}$

Professor Lewicki was a member of many scholarly associations, among which the following should be listed: the Polish Academy of Sciences, the Polish Academy of Arts and Sciences, Académie des Sciences d'Outre-Mer, Association Internationale d'Études des Civilisations Méditerranéennes, Royal Asiatic Society, Körösi Csoma, the Polish Oriental Society and Polish Folkloric Society.

It should also be mentioned that within the Polish Academy of Sciences he directed the Department of $\mathrm{Nu}-$ mismatics, which he himself established within the Institute of Material Culture, later moved to the Jagiellonian University and renamed the Laboratory of Oriental Sources and Numismatics within the Institute of Oriental Stud-

42 T. LEWICKI, Ze studiów nad geografią historyczną Afryki. Królestwo Organa map europejskich, "Przegląd Orientalistyczny" 1970, no. 3, pp. 183-198.

43 Interview with Dr U. Lewicka-Rajewska, Professor T. Lewicki's daughter, 20.06.2016. 
ies. ${ }^{44}$ Its aim was to conduct comprehensive research into coin findings in Poland. This resulted from the fact that Lewicki had noted the need for studies into the Arabic coins found in Poland and neighbouring countries, as he considered them to be an important source for research into the early history of the Polish state, especially since written sources from this period are scarce. ${ }^{45}$ Due to his passion as a collector, he was a valued numismatist, considered in these circles to be an exceptional expert on the topic, which is also attested by his various academic publications, such as Eamane ozdoby jako namiastka srebrnej monety we wczesnośredniowiecznym Maghrebie [Broken adornments as surrogate silver coins in medieval Maghreb]. ${ }^{46}$ For many years, the professor was also the editor-in-chief of the academic journal "Folia Orientalia". ${ }^{47}$

In recognition of his merits in the field of oriental philology, in February 1986, Professor Lewicki received a honoris causa doctorate from the University of Wrocław, which he valued highly, as he considered this university to be the successor of the Jan Casimir University in Lvivis ${ }^{48}$.

44 AJU, reg. no. SIII 246, T. Lewicki's personnel file, Work permit for the Institute of the History of Material Culture of the Polish Academy of Sciences, Ministry of Higher Education. Department of University Studies, Warsaw, 29.06.1954.

45 U. LEWICKA-RAJEWSKA, Pracownia Źródeł Orientalnych i Numizmatyki przy Instytucie Orientalistyki - zlikwidowana, "Alma Mater" 2012, no. 150, pp. $43-46$.

${ }_{46}$ T. LEWICKI, Eamane ozdoby jako namiastka srebrnej monety we wczesnośredniowiecznym Maghrebie, "Wiadomości Numizmatyczne" 1958, vol. 2/1, pp. 11-14.

47 A. MAŁECKA, op. cit., p. 12.

48 Tadeusz Lewicki, Uniwersytet Wrocławski, [on-line:] http://uni. wroc.pl/o-nas/nagrody-i-wyr\% $\mathrm{C}_{3} \% \mathrm{~B}_{3} \% \mathrm{C}_{5} \% \mathrm{BC}$ nienia/doktorzy-hono ris-causa/tadeusz-lewicki - 11.05.2016. 
Professor Lewicki was also awarded the Knight's Cross of the Order of Polonia Restituta, the Gold Cross of Merit and the Medal of the Commission of National Education. ${ }^{49}$

Tadeusz Lewicki died in Kraków on $22^{\text {nd }}$ November 1992 and was buried at the Rakowicki cemetery. He led a rich life, filled with passion, which is reflected well in the fragment of his necrology cited in Alicja Małecka's memoirs: "[...] after a long and happy life, he died in Kraków".50 He was remembered by his co-workers as an exceptionally hard-working person, an effective organiser and a distinguished scholar. He was also a fantastic educator, and his lectures were extremely popular with the students. Throughout the entire period of his activities at the Jagiellonian University, he was surrounded by an aura of patriotism and adventure. In the harsh grey reality of Socialist Poland, it seemed almost as if he was someone from another world. ${ }^{51}$

Professor Lewicki was a distinguished specialist in Oriental studies, which encompasses his achievements in the fields of linguistics, Arabic and African studies. In the field of African research, he specialized in the region of North Africa and Sudan, understood as a historical land extending to the south of the Sahel and referred to by the Arabs as Sudan, in Arabic - Bilād as-Sudan. In African studies circles, he was considered to be well-versed in these issues and a scientific expert on the topics, which led to him being invited to African studies congresses and being entrusted by an international editing team with writing one of the

\footnotetext{
49 J. BubKa, B. Ostafin, op. cit., pp. 172-173.

50 "[...] po długim i szczęśliwym życiu zmarł w Krakowie": A. MAŁECKA, op. cit., p. 12.

${ }^{51}$ Interview with Dr A. Małecka, Kraków, 3.11.2016.
} 
chapters of a multi-volume history of Africa published by UNESCO. ${ }^{52} \mathrm{~A}$ large part of his scientific activities can undoubtedly be included among the achievements of the Polish African studies, placing him among the most renowned representatives of these academic circles. It is significant to note that the last paper Prof. Lewicki presented in his lifetime, entitled " $Z$ przeszłości Afryki na południe od Sahary - epoka przedkolonialna" [From the history of Africa south of the Sahara - the precolonial era] - at a scientific session of the Polish Oriental Society, was dedicated to the history of Africa. ${ }^{53}$ Lewicki himself frequently referred to his own research as being part of African studies, while his home was not lacking in souvenirs and items linked to the African continent. ${ }^{54}$

It should also be emphasized that Professor Lewicki was married to Anna Kowalska-Lewicka (1920-2009), an ethnographer, daughter of the distinguished Orientalist Professor Tadeusz Kowalski. Doctor Anna Kowalska-Lewicka conducted research in such countries as Senegal and Mauretania into the dairy farming of the nomadic Fulbe and Moors, inhabiting the Mauretania Saharan region. ${ }^{55}$ She stayed there together with her husband within the framework of the scientific mission financed by the In-

52 J. HaUzIŃski, Więcej niż jedno życie, czyli o profesorze Tadeuszu Lewickim (1906-1992), "Litteraria Copernicana" 2014, vol. 1 (13), p. 178, [on-line:] http://apcz.pl/czasopisma/index.php/LC/article/view/ LC.2014.012/4197-15.01.2016.

53 A. ZABORSKI, op. cit., p. 7.

54 Interview with Dr U. Lewicka-Rajewska, Prof. T. Lewicki's daughter, Kraków, 15.09.2016.

55 A. SpISS, Dr Anna Kowalska-Lewicka (1920-2009), "PAUza Akademicka” 2009, no. 59, p. 3, [on-line:] http://pauza.krakow.pl/59_3_ 2009.pdf - 12.05.2016. 
stitut Fondamental d'Afrique Noire - IFAN in Dakar. She was also the author of the book Mauretania published in $1976^{56}$ and of an academic article dedicated to the women of M'zab: Modern changes of women's life in M'Zab, Algieria. ${ }^{57}$

On $17^{\text {th }}-18^{\text {th }}$ November 1993, an academic session took place in the Polish Academy of Sciences dedicated to the memory of Professor Lewicki. ${ }^{58}$

LIST OF SELECT ACADEMIC PUBLICATIONS WRITTEN BY PROFESSOR TADEUSZ LEWICKI AND PAPERS PRESENTED AT SCIENTIFIC CONFERENCES AND ORIENTAL STUDIES COMMISSIONS OF THE POLISH ACADEMY OF SCIENCES REFERRING TO AFRICA

List in chronological order according to the date of publication.

- Le Culte du Bélier dans la Tunisie Musulmane, Extrait de la "Revue des Études Islamiques" 1936, pp. $195-200$.

- Une langue romane oubliée de l'Afrique du Nord. Observations d'un arabisant, "Rocznik Orientalistyczny" 1953, vol. 17, pp. 415-48o.

- Études ibāḍites nord-africaines. Partie I: Tasmiya Šuyūh̆ Ğabal Nafūsa wa-qurāhum. Liste anonyme des šayḥs ibādites et des localités du Ğabal Nafüsa contenue dans le 'Siyar al-mašā'iḥ' (Vie-XIIe s.) Texte ar-

${ }^{5}$ A. KowAlsKa-LewickA, Mauretania, Wiedza Powszechna, Warszawa 1976.

57 EAdem, Modern changes of women's life in M'Zab, Algieria, "Ethnologia Polona" 1991, vol. 15/16.

58 B. MichalaK, Sesja naukowa poświęcona pamięci Profesora Tadeusza Lewickiego, "Przegląd Orientalistyczny" 1994, no. 1-2, p. 94. 
abe avec introduction, commentaire et index, "Prace Orientalistyczne" 1955 , vol. 4.

- Eamane ozdoby jako namiastka srebrnej monety we wczesnośredniowiecznym Maghrebie, "Wiadomości Numizmatyczne" 1958, vol. 2/1, pp. 11-14.

- Les ibādites en Tunisie au Moyen Âge, A. Signorelli, Roma 1959.

- Quelques extraits inédits relatifs aux voyages des commerçant et des missionaires ibādites nord-africains au pays du Soudan occidental et central au Moyen Âge, "Folia Orientalia" 1960-1961, vol. 2, pp. 1-27.

- Z dziejów handlu transsaharyjskiego: kupcy i misjonarze ibādyccy $w$ zachodnim $i$ środkowym Sudanie w VIII-XII w., "Przegląd Orientalistyczny" 1961, no. 1 (37), pp. 3-18.

- Najstarsza wzmianka o stosunkach Arabii muzutmańskiej ze wschodnim wybrzeżem Afryki, offprint from: "Sprawozdanie z posiedzeń Komisji Oddziału PAN w Krakowie” 1962 (January-June).

- Z przeszłości Afryki na południe od Sahary, offprint from: "Sprawozdanie z posiedzeń Komisji Oddziału PAN w Krakowie" 1962 (July-December).

- Poczatki państwowości $w$ Zachodnim Sudanie, offprint from: "Sprawozdanie $z$ posiedzeń Komisji Oddziału PAN w Krakowie” 1963 (January-June).

- Pożywienie ludności Zachodniej Afryki w średniowieczu według źródeł arabskich, "Etnografia Polska" 1963, vol. 7, pp. 31-191.

- Materiaty do bibliografii Zachodniej Afryki za lata 1957-1961, "Materiały Zachodniopomorskie" 1963, vol. 9, pp. 359-468. 
- Początki państwa Kānem - Bornū, offprint from: "Sprawozdanie z posiedzeń Komisji Oddziału PAN w Krakowie" 1964 (July-December).

- Z przeszłości Nubii, "Przegląd Orientalistyczny" 1965, no. 3 (55), pp. 215-228.

- Animal Husbandry Among Mediaeval Agricultural People of Western and Middle Sudan (According to Arab Sources), "Acta Ethnographica Hungarica" 1965, vol. 14, notebook 1-2, pp. 165-178.

- Z przeszłości Zachodniej Afryki, "Materiały Zachodniopomorskie" 1965, vol. 11, pp. 679-717.

- Źródła arabskie do dziejów Afryki na południe od Sahary, "Etnografia Polska" 1965, vol. 9, pp. 221-293.

- Arabski handel niewolnikami murzyńskimi do końca XVI w., offprint from: "Sprawozdanie z posiedzeń Komisji Oddziału PAN w Krakowie” 1966 (July-December).

- Awunkulat w średniowiecznej Afryce, "Etnografia Polska" 1966, vol. 10, pp. 445-449.

- Przeżytki starych kultów i wierzeń pogańskich u średniowiecznych Berberów doby muzułmańskiej, "Lud" 1966, vol. 50, pp. 230-296.

- Najważniejsze problemy historiografii Afryki Subsaharyjskiej na międzynarodowym Kongresie Historii Afryki w Dar es Salaam (26 IX - 3 X 1965), "Etnografia Polska" 1967, vol. 11, pp. 225-264.

- Średniowieczni pisarze arabscy o bogactwach mineralnych Afryki i ich eksploatacji, "Studia z Dziejów Górnictwa i Hutnictwa” 1967, vol. 11, pp. 7-112.

- Archeologia na międzynarodowym Kongresie Historii Afryki w Dar es Salaam w 1965, "Archeologia Polski" 1969, vol. 1 (14), pp. 255-266. 
- Dzieje Afryki od czasów najdawniejszych do XIV w. Wybrane zagadnienia, Uniwersytet Warszawski. Studium Afrykanistyczne, Warszawa 1969.

- Arabic External Sources for the History of Africa to the South of Sahara, Zakład Narodowy im. Ossolińskich, Wydawnictwo Polskiej Akademii Nauk, Wrocław - Warszawa - Kraków 1969.

- Ze studiów nad geografia historycznq Afryki. Królestwo Organa map europejskich XIV-XVI w., "Przegląd Orientalistyczny" 1970, no. 3 (75), pp. 183-198.

- Zāfünu - nieznane średniowieczne królestwo sudańskie, offprint from: "Sprawozdanie z posiedzeń Komisji Oddziału PAN w Krakowie” 1970.

- Arabic External Sources for the History of Africa to the South of Sahara, Wrocław 1969, Prace Komisji Orientalistycznej PAN, no. 9.

- The Ibadites in Arabia and Africa, "Journal of World History" 1971, vol. 13, pp. 51-130.

- West African food in the Middle Ages. According to Arabic Sources, London 1974.

- Études maghrébines et soudanaises I, "Prace Orientalistyczne" 1976, vol. 22.

- L'origine nord-africaine des Bafour, [in:] Actes du Deuxième Congrès International D'Étude des Cultures de la Méditerranée Occidentale, Alger 1978, pp. 145-154.

- Études maghrébines et soudanaises II, "Prace Orientalistyczne" 1983, vol. 26.

- Gannar - Le Nom Wolof de la Mauritanie, "Paideuma. Mitteilungen und Kulturkunde" 1989, vol. 35, pp. 177-179. 
- The Role of the Sahara and Saharians in the Relationships between North and South, [in:] General History of Africa, vol. 3: Africa from the $7^{\text {th }}$ to the $11^{\text {th }}$ Century, ed. by I. Hrbek, London 1992.

I would to like to express my gratitude to Dr Urszula Lewicka-Rajewska, Prof. Tadeusz Lewicki's daughter, for participating in the interview and providing access to the family archives, and Dr Alicja Małecka, a long-term research and didactic employee of the Institute of Oriental Studies, for participating in the interview and sharing information about Professor Tadeusz Lewicki.

\section{BIBLIOGRAPHY}

Archive of the Jagiellonian University (AJU), personnel files of JU employees, reg. no. SIII 246 (Tadeusz Lewicki).

BubKA Jolanta, Ostafin Barbara, Tadeusz Lewicki (1906-1992), [in:] Studia Orientalia Thaddaeo Lewicki Oblata. Materiaty sesji naukowej poświęconej pamięci profesora Tadeusza Lewickiego, Kraków, 17-18 listopada 1993, ed. by E. GóRSKA, B. OsTAFIN, Uniwersytet Jagielloński, Instytut Filologii Orientalnej, Kraków 1994.

HAUZIŃSKI Jerzy, Więcej niż jedno życie, czyli o profesorze Tadeuszu Lewickim (1906-1992), "Litteraria Copernicana" 2014, vol. 1 (13), [on-line:] http://apcz.pl/czasopisma/index.php/LC/article/ view/LC.2014.012/4197.

Kolokwium naukowe ku czci profesora Tadeusza Lewickiego w pierwszq rocznicę śmierci (1993), "Africana Bulletin" 1994, vol. 42.

Kościelniak Krzysztof, The contribution of Prof. Tadeusz Lewicki (1906-1992) to Islamic and West African studies, "Analecta Cra- 
coviensia" 2012, vol. 44, [on-line:] http://bc.upjp2.edu.pl/dli $\mathrm{bra}$ /plaincontent?id=1114.

KowALSKA-LeWICKA Anna, Mauretania, Wiedza Powszechna, Warszawa 1976.

KoWALSKA-LEWICKA Anna, Modern changes of women's life in M'Zab, Algieria, "Ethnologia Polona" 1991, vol. 15/16.

KuCZYŃSKI Antoni, Korzenie i wspótczesność polskich badań etnologicznych w Afryce, "Etnografia Polska" 1994, vol. 38, no. 1-2.

LEWICKA-RAJEWSKA Urszula, Pracownia Źródeł Orientalnych i Numizmatyki przy Instytucie Orientalistyki - zlikwidowana, "Alma Mater" 2012, vol. 150.

MaciUszaK Kinga, $Z$ historii orientalistyki na Uniwersytecie Jagiellońskim, "Alma Mater" 2009-2010, no. 120-121.

Maєecka Alicja, Profesor Tadeusz. Wspomnienie o Profesorze Tadeuszu Lewickim (1906-1992), "Cracovia Leopolis" 1998, no. 15.

MańczaK Witold, Prace romanistyczne profesora Tadeusza Lewickiego, [in:] Studia Orientalia Thaddaeo Lewicki Oblata. Materiaty sesji naukowej poświęconej pamięci profesora Tadeusza Lewickiego, Kraków, 17-18 listopada 1993, ed. by E. GórSKA, B. OsTAFIN, Uniwersytet Jagielloński, Instytut Filologii Orientalnej, Kraków 1994.

MichalaK Barbara, Sesja naukowa poświęcona pamięci Profesora Tadeusza Lewickiego, "Przegląd Orientalistyczny" 1994, no. 1-2. Rozynek Józef, ZıóŁKowski Józef, Doktorzy honoris causa Uniwersytetu Wrocławskiego 1948-2002, Wydawnictwo Uniwersytetu Wrocławskiego, Wrocław 2002.

Sourdel Dominique, Sourdel Janine, Cywilizacja islamu, trans. by M. Skuratowicz, W. Dembski, PIW, Warszawa 1980.

SPISS Anna, Dr Anna Kowalska-Lewicka (1920-2009), "PAUza Akademicka" 2009, no. 59, [on-line:] http://pauza.krakow.pl/59_ 3_2009.

Tadeusz Lewicki, [in:] Powstańcze biogramy, [on-line:] http://www. 1944.pl/historia/powstancze-biogramy/Tadeusz_Lewicki_1. Wielka Encyklopedia PWN, PWN, Warszawa 2003, vol. 18. 
ZAborski Andrzej, Min Bilād Aş-Şaquāiba Ilā Bilād As-Sūdān - od Stowiańszczyzny po Sudan, [in:] Studia Orientalia Thaddaeo Lewicki Oblata. Materiały sesji naukowej poświęconej pamięci profesora Tadeusza Lewickiego, Kraków, 17-18 listopada 1993, ed. by E. Górska, B. Ostafin, Uniwersytet Jagielloński, Instytut Filologii Orientalnej, Kraków 1994.

ZABORSKI Andrzej, Tadeusz Lewicki (1906-1992), [in:] Złota księga Wydziału Filologicznego, ed. by J. Michalik, W. WALECKI, Księgarnia Akademicka, Kraków 2000. 